\title{
GENDER AND INVOLVEMENT IN COMMUNITY DEVELOPMENT. A STUDY OF IHIOMA IN ORLU L.G.A, IMO STATE, NIGERIA
}

\author{
Monday, Ukpabi \\ Department of Sociology \\ Imo State University, Owerri, Imo State, Nigeria
}

\begin{abstract}
This research focused on "men and women in community development in Ihioma community, in Orlu local government area State. The broad objective of this study is to investigate men and women effects in community development in Ihioma. Two hypothesis were formulated in the course of this study relevant literature were reviewed, two theories, were also reviewed, the theories are modernization theory of social change and the cultural feminist theory. The researcher adopted the cultural feminist theory in the explication in Ihioma, the researcher adopted the survey research design, the researcher also adopted a sample size of 229 respondents the purposive sampling method was also adopted by the researcher. The research gathered data for this research through the techniques. Data were analyzed using the chisquare statistical tool. The hypothesis which states that there is no significant relationship between gender disparity and men and women involvement in community development was also rejected as the table value of 7.815 was greater than the $x^{2}$ value of 6.8 . The study found out that gender disparity in Ihioma has not led to a decline in community development. The study also found out that the level of education among men and women in Ihioma has not affected the process of development in the area.
\end{abstract}

Keywords - Women, Community, Development, Gender disparity, Education.

\section{INTRODUCTION}

Globally, women participation in community development has been less than discouraging despite their numerical strength. The situation has grown worst that it has generated both national and international recognition. Despite the fact that women are now gradually coming out to participate in the development of their various communities, they are still largely marginalized by the male folks. This is because the traditional African society views women as people who should take care of the home, and not participating in community development. Women empowerment remains the key point of the Beijin conference held in China in 1995. The number three (3) item in the table of millennium development goals is Gender equity and women empowerment. Before Millennium Development Goals (MDGs) programme, there has been other global treaties, declarations and conventions in women such as the one held in Mexico, Nairobi, Dakar and New York in 1975, 1994 and 2000 respectively.

In Nigeria, various interventions and conferences such as the one held in 1989 was embarked upon to improve the status of women in the society. Nigeria is a signatory to many international organizations such as convention in elimination of all forms of discrimination against women (CEDAN) signed on $13^{\text {th }}$ June 1985. All these efforts made by both Nigerian government and international communities point to the fact that women participation in development has remained abysmally poor both in the developed and developing nations, but the situation is worst in developing countries like Nigeria where women are regarded as inferior and second class citizens. It has become incontrovertibly clear among the policy makers and international agencies that women constitute bulk of Nigerian population and they are indispensable in the issues of community development (Henry, 2016). The 2006 national population census reveals that women make up $48.78 \%$ (about half) of the population Wole(2016).

Despite the numerical strength of women, as revealed by the census, women are under-represented almost in all aspect of the nation's economy such as politics, education, agriculture, business enterprise etc. The Nigerian society is so patrilineal that women are expected to confirm to and confine themselves to their male counterpart. They (women) therefore operate within the scope allowed them by the men, who see them as mere home managers incapable of making/contributing to sound policy decision making process. This has greatly affected the development of the various Nigerian communities especially Ihioma community.

According to United Nation (2008), the productive use of all human resources is a key factor in development. It is argued that if women are to join forces with their male counterparts at all level of development the pace of development will be accelerated. This study tends to compare women and men efforts in community development in Ihioma community in Orlu local government area in Imo State. 


\section{OBJECTIVE OF THE STUDY}

To examine whether gender disparity has brought about community development in Ihioma community

\section{HYPOTHESIS}

There is no significant relationship between gender disparity and community development.

\section{LITERATURE REVIEW AND THEORETICAL FRAMEWORK}

According to Olu and Mgbo (2014), the African society is characterized by male dominancy, which makes it so difficult for women to participate in community development. According to them, women are mostly seen around the house caring for the family. They maintained that women are largely marginalized, and until this marginalization stops, developmental issues in Nigeria and Africa at large will still remain in the dark. Chukwu (2014), argues that women are the reason why they cannot contribute their own quota to their various community development. Until women stop the blame factor, that they will remain permanent stranger in the area of community development. Murel (2013), has claimed that women predominate among the poor in the world today, and they are more in the rural areas. Their annual incomes throughout the world have declined so sharply in recent years that they have fallen below poverty line. According to Jeremiah (2009), women are getting poorer and further marginalized both in the utilization of available resources to access development resources. Although, male chauvinists may be right in saying that women are affected by poverty, it is clear to the most simplistic analyst that women are far more disadvantaged and more vulnerable. Ali (2013) was against the above ascertain for him, women are gradually coming out to participate in the development of their various communities, through the sponsorship of girl-child education, some women have built health centre, schools, parks in their various communities. He said that despite the fact that the men will always want to dominate that women are now gradually rejecting their old roles as home keepers and children bearers. Despite the above assertion, the UNDP report (2006) claimed that majority of African women still work for between 14-18 hours per day and produce between 50-80 percent of sub-Saharan African's food, fetch water, gather firewood, and care for the family. In Nigerian, according to Ijere (1991), women form over half of the rural population and it is estimated that $80 \%$ of rural labour force is provided by women. Another estimate by the UNDP (2013), claimed that about one third of all African households are headed by women. In terms of sectional allocation, agriculture appears to be the occupation of $70.3 \%$ of Nigeria women. Yet, it is known that agriculture has the largest chunk of the poor for women, the poverty is compounded by the fact that only $8 \%$ of women hold title to the land they work on (UNFPA, 2009). In the education sector, women also fare worse than men. For example, $46.3 \%$ of female worldwide are considered illiterate (Martins, 2014). Nwadi (2015) is of the opinion that women contribute to the development of their various communities by coming together through a general meeting known as the August meeting. In August meeting, women discuss issues affecting their various communities, and also proffer solutions to the problems affecting their various communities. He asserted that despite these efforts been still not happy with them because of the belief that women are not supposed to develop any other aspect of the society except the family. Hence, Chibundu 2015 and Oluebube (2016) asserted that gender bias has significantly affects development in Nigeria, because when women are not given the opportunity like their male counterpart. The modernization is a theory used to explain the process of modernization within societies and it was popularized by Walter, Rowstow, W.A. Lewis, and Talcott Parsons etc. The theory works at the internal factors of a society while assuming that with assistance, traditional societies can be brought to development. This theory attempts to identify the social variables which contribute to social progress and development of societies. Modernization theory do not only stress the process of change, but also the responses to that change. Development begins with a change in behavioural practices of individuals or groups, and as the number of individuals who exhibits new behavior increase, it reaches a critical stage, and become the basis for new norms.

\section{METHODOLOGY}

The scope of this study is to analyze men and women effort in community development in Ihioma community in Orlu local government area, Imo State. The research design for this work is the survey research design. The researcher adopted survey research deign because of its flexibility to permit the use of multiple data collection techniques. The area of this study is Ihioma community, in Orlu local government area of Imo State. Ihioma is a community in Orlu local government area. The community is known for her hospitable nature. Ihioma people are mainly farmous, which has contributed greatly in wiping out hunter in the community. The community has undergone series of development processes, which both men and women are part of. The population of this study consists of both men and women in Ihioma community which is currently unknown, however, the researcher purposively chose a sample of 250 respondents. The respondents were drawn from 5 villages out of the 8 villages in Ihioma and they were purposively selected.

Table 3.1: Sample Size Distribution of Respondents

\begin{tabular}{|l|l|l|}
\hline ITEM & $\begin{array}{l}\text { VILLAGES } \\
\text { DEPARTMENT }\end{array}$ & RESPONDENTS \\
\hline 1. & Okwuekpe & 50 \\
2. & Umudim & 50 \\
3. & Umuezikeodu & 50 \\
\hline
\end{tabular}




\begin{tabular}{|l|l|l|}
\hline 4. & Ebenese & 50 \\
5. & Umunquma & 50 \\
\hline Total & & $\mathbf{2 5 0}$ \\
\hline
\end{tabular}

The sampling techniques for this study is the purposive sampling technique. Purposive sampling is a nonprobability sampling techniques that selects elements in a sample on the basis of sole judgment usually in terms of knowledge of the selected particular individual or organization in the subject under study. In using this techniques, the research purposively distributed 50 questionnaire to the 5 purposively selected village in Ihioma. In this study, the researcher will administered questionnaire to the purposively selected respondents in Ihioma community. The questionnaire consist of two sections, section A and B. Section A consist of the demographic data of respondents, while section $\mathrm{B}$ consist of question, and the respondents are expected to tick "SA" for strong agree, "A" for agree "SD" for strongly disagreed " $\mathrm{D}$ " for disagree.

Secondary data are already made information about the topic under study, and they are contained in text books, journals, magazines, articles and community archival documents kept by some enlightened persons

Data was presented using simple percentage and tables, while the hypotheses were tested using the chi-square $\left(\mathrm{x}^{2}\right)$ statistical tool.

Formular for chi-square (X2)

$\sum \frac{(\mathrm{O}-\mathrm{E})}{\mathrm{E}}$

$\begin{array}{lll}\mathrm{O} & = & \text { Observed frequency } \\ \mathrm{E} & = & \text { Expected frequency } \\ \Sigma & = & \text { Summing over the cells. }\end{array}$

test this hypothesis, the responses of the respondents in item 3 and 4 as represented in table 4.1.6.

Table 4.2.1 Chi-square Analysis for Gender Disparity and Community Development

\begin{tabular}{|l|l|l|l|l|l|}
\hline ITEMS & SA & A & D & SD & TOTAL \\
\hline 3 & 58 & 58 & 50 & 63 & $229 B_{1}$ \\
\hline 4 & 126 & 80 & 10 & 13 & $229 B_{2}$ \\
\hline Total & $\mathbf{1 8 4 A}_{\mathbf{1}}$ & $\mathbf{1 3 8 A}_{\mathbf{2}}$ & $\mathbf{6 0 A}_{\mathbf{3}}$ & $\mathbf{7 6 A}_{\mathbf{4}}$ & $\mathbf{4 5 8}$ \\
\hline
\end{tabular}

Computing formula for chi-square

$\mathrm{x}^{2}=\underset{\mathrm{E}_{1}}{\sum\left(0_{1}-\mathrm{E}_{1}\right)^{2}}$

Where:

$\sum \quad=\quad$ Summation

$0 \quad=\quad$ Observed values

$\mathrm{E} \quad=\quad$ Expected values

To obtain the expected frequencies

$\mathrm{E}=\underline{\text { Row total } \mathrm{x} \text { column }}$

Ground total

Cell $\mathrm{A}_{1} \mathrm{~B}_{1} \underline{184 \times 229}$

$=92$

458

Cell $\mathrm{A}_{2} \mathrm{~B}_{1} \underline{138 \times 229}$

$=69$

458

Cell $\mathrm{A}_{3} \mathrm{~B}_{1} \frac{60 \times 229}{458}$

Cell $\mathrm{A}_{4} \mathrm{~B}_{1} \underline{76 \times 229}$

$=38$

VI

RESULT AND DISCUSSION

Table II Men and Women in Market Development

Cell $\mathrm{A}_{1} \mathrm{~B}_{2} \underline{184 \times 229}=92$

\begin{tabular}{|l|l|ll|}
\hline S/N & QUESTIONS & POSITIVE & \\
\hline 1. & $\begin{array}{l}\text { Women are not more involved than men } \\
\text { in the development of the market in } \\
\text { Ihioma }\end{array}$ & $200(87: 3)$ & C \\
\hline 2. & $\begin{array}{l}\text { Men are mostly involved in the building } \\
\text { of market structures in Ihioma }\end{array}$ & $39(17.1)$ & C \\
\hline 3. & $\begin{array}{l}\text { Women have significant influence than } \\
\text { men in the socio economic development } \\
\text { of Ihioma }\end{array}$ & $116(50.7)$ & P \\
\hline 4. & $\begin{array}{l}\text { Ihioma woman are still very much } \\
\text { underrepresented in the development } \\
\text { process of their communities compare to } \\
\text { the male folks when it comes to socio- } \\
\text { economic growth of Ihioma }\end{array}$ & & \\
\hline
\end{tabular}

\section{Testing of Hypothesis}

Ho: There is no significant relationship between gender disparity of men and women and community development to

\begin{tabular}{|c|c|c|c|c|c|}
\hline \multicolumn{5}{|c|}{458} & \\
\hline \multicolumn{2}{|c|}{ NEGATIVE } & $\%$ & \multicolumn{2}{|c|}{ TOTAL } & \\
\hline \multicolumn{2}{|c|}{ 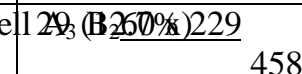 } & $€ 00$ & \multicolumn{2}{|c|}{229} & \\
\hline \multicolumn{2}{|c|}{ e|l 190B $\frac{82.9 \times 229}{458}$} & Ю08 & \multicolumn{2}{|c|}{229} & \\
\hline \multirow{2}{*}{\multicolumn{2}{|c|}{$\begin{array}{l}113(49.3) \\
\text { lacing the observed a } \\
\text { orm, we have; } \\
\text { able34(.262\%d)ata for } \mathbf{H}\end{array}$}} & $\begin{array}{l}1000 \\
d \text { the ex }\end{array}$ & $\begin{array}{r}22 \\
\text { cted }\end{array}$ & values in & \\
\hline & & \multicolumn{3}{|c|}{ able34(.R62\%d)ata for Hypothesis One29 } & \\
\hline 0 & $\mathbf{E}$ & (0-E) & & $(\mathbf{0}-\mathbf{E})^{2 / \mathrm{E}}$ & \\
\hline 58 & 92 & -34 & & \begin{tabular}{|l|}
0.7 \\
\end{tabular} & \\
\hline 58 & 69 & -11 & & 0.3 & \\
\hline 50 & 30 & 20 & & 1.3 & \\
\hline 63 & 38 & 25 & & 1.3 & \\
\hline 126 & 92 & 34 & & \begin{tabular}{|l|}
0.7 \\
\end{tabular} & \\
\hline
\end{tabular}




\begin{tabular}{|l|l|l|l|}
\hline 80 & 69 & 11 & 0.3 \\
\hline 10 & 30 & -20 & 1.3 \\
\hline 13 & 38 & -25 & 1.3 \\
\hline Total & & & $\mathbf{7 . 2}$ \\
\hline
\end{tabular}

The table above is a $4 \times 2$ contingency table, hence the degree of freedom.

$(\mathrm{df})=(\mathrm{c}-1)(\mathrm{R}-1)$

$(\mathrm{df})=(4-1)(2-1)$

$\mathrm{df}=3 \times 1=3$

Thus, $\mathrm{df}=3$

The table value of $x^{2}$ at a significance level of 0.05 and degree of $3=7.815$. The calculated value of $x^{2}=7.2$. Since the calculated value of $x^{2}$ is less than the table value of $x^{2}$, we therefore reject the null hypothesis which states that there is no significant relationship between gender disparity of men and women and community development.

\section{Discussion of findings}

From the study carried out on gender and involvement in development, We found out that gender disparity in Ihioma has not led to a decline in community development, that both men and women have been contributing greatly to the development of Ihioma as a community. This is in line with what Nwadi (2015) said, that me and women contribute greatly to the development of their various communities by forming different associations that will help drive home development.

\section{CONCLUSION}

A cursory work at the entire work especially of the findings made in the course of the study reveals that there is still a yawning gap in the level of involvement of men and women in development.

This less involvement of the female folks has contribute in no small measure to the backwardness of the country despite the enormous resources with which the country is endowed. It has to a great extent slowed down the pace at which communities grow and development. Therefore, if the Nigerian society should develop like other countries of the world, there is urgent need to get more Nigerian women involved in the development of every facet of the country. This will help to pull all the human resources together for the upliftment of the society.

\section{RECOMMENDATION}

Based on the research carried out on men and women in development, in Ihioma, in Orlu local government area, Imo State, $\mathrm{t}$

That more women should be allowed to participate in the development of their various communities

\section{REFERENCE}

[1] Akpan, K. (2015). Men and women involvement in community development Lagos: Ajao publishing company. (pp. 62-69).

[2] Batten, P. (2012). Men and community development in New York. Journal of sociology of development 18 (13) 28-35.

[3] Erute, F. (2016). Community development and women empowerment in African. Journal of developmental studies 12(3) 55-57

[4] Ekon, E. (2016). The impact of women in community development. Lagos: Oshodi printing press.) pp.39-45.

[5] Effiong, A. (2016). Nigerian women and community development. Uyo: Emem Akpan publishing Co. Ltd. PP. 23-27

[6] Folusho, A. (2015). Changing role of women and community development. Journal of social-psychology. 8(7) 17-25. pp.35 -42.

[7] Ikenna I and Uwadi C. (2016).Career Women and Family Stability in Nigeria. Journal of Gender and Population Studies. 12(11) (pp.12-20).

[8] Ijere,A.(1991). Africans and communal living. Akure:Malomo printing press Ltd.

[9] Martins, A (2016).Gender and community development. Journal of sociological studies 10 (10) 12-16.

[10] Mbah,H. (2016). Women and development in African South-South Journal of development 10 (10) 17-23.

[11] Njoku, C. (2013). The Nigerian women and community development. A Journal of women and development (4) 221-241.

[12] Nwadi, O. (2015). Women empowerment and community development Aba: Joshua academic press Ltd.

[13] R. Mehul, "Discrete Wavelet Transform Based Multiple Watermarking Scheme", in Proceedings of the 2003 IEEE TENCON, pp. 935-938, 2003.

\section{ACKNOWLEDGEMENTS}

We are greatful to Dr. D.I Nkwocha for his unreserved assistance during the course of this work. We also acknowledge all the authors that their works were cited in this research. 